\title{
Pelvic splenosis mimicking ovarian metastasis of breast carcinoma: a case report
}

Meme karsinomunda over metastazını taklit eden pelvik splenozis: Bir olgu sunumu

\author{
JaleMetindir ${ }^{1}$, Hakan Hüsnü Mersin ${ }^{2}$, Melda Zarife Bulut ${ }^{3}$ \\ 'Department of Gynecology, Ankara Oncology Education and Research Hospital, Ankara, Turkey \\ 2Department of Surgery, Ankara Oncology Education and Research Hospital, Ankara, Turkey \\ 3.Department of Pathology, Ankara Oncology Education and Research Hospital, Ankara, Turkey
}

\section{Abstract}

Splenosis is the heterotopic autotransplantation of splenic tissue that usually follows traumatic splenic rupture and splenectomy. Implanted splenic tissue may give rise to a mass or masses in the chest, abdomen, or pelvis which the clinician must distinguish from benign or malignant tumors. A 38-year-old multiparous woman presented for a routine gynecological examination during breast cancer treatment. She had undergone splenectomy following traumatic splenic rupture at the age of 13. Pelvic examination revealed a left adnexal mass. Transvaginal ultrasonography showed a 39x56x40 mm diameter hyperechoic, hypervascular solid tumor on the left ovary. Total abdominal hysterectomy and bilateral salpingo-oophorectomy was performed. The postoperative histological diagnosis was splenic tissue. Splenosis must be considered in the differential diagnosis of previosly splenectomized patients who present with unexplained masses.

(J Turkish-German Gynecol Assoc 2011; 12: 130-2)

Key words: Splenosis, splenectomy, adnexal mass

Received: 20 June, 2010

Accepted: 20 August, 2010
Özet

Splenozis, travmatik dalak rüptürü ve splenektomiyi takiben dalak dokusunun heterotopik ototransplantasyonudur. İmplante olan dalak dokusu klinisyenin karşısına göğüs boşluğu, karın boşluğu veya pelviste, iyi yada kötü huylu tümörlerden ayırmasını gerektiren kitle veya kitleler olarak çıkabilir. Otuzsekiz yaşında multipar kadın hasta meme kanseri tedavisi sırasında rutin jinekolojik muayene için başvurdu. Onüç yaşında, travmatik dalak rüptürünü takiben splenektomi geçirmişti. Pelvik muayenede sol adneksiyal kitlesi vardı. Transvaginal ultrasonografide sol over üzerinde $39 \times 56 \times 40 \mathrm{~mm}$ çaplarında hiperekoik, hipervasküler solid tümör saptandı. Total abdominal histerektomi ve salpingoooferektomi yapıldı. Operasyon sonrası patolojik tanı dalak dokusu olarak geldi. Splenozis daha önce splenektomi geçiren hastalarda açılanamayan bir kitle saptanıldığında ayırıcı tanıda düşünülmesi gereken bir durumdur.

(J Turkish-German Gynecol Assoc 2011; 12: 130-2)

Anahtar kelimeler: Splenozis, splenektomi, adneksiyal kitle

Geliş Tarihi: 20 Haziran 2010

Kabul Tarihi: 20 Ağustos 2010

\section{Introduction}

Splenosis is the heterotopic autotransplantation of splenic tissue that usually follows traumatic splenic rupture and splenectomy (1). Implanted splenic tissue may give rise to a mass or masses in the chest, abdomen, or pelvis which the clinician must distinguish from benign or malignant tumors (2). Splenosis is usually asymptomatic, but there are reported complications directly related to splenosis. Occasionally, patients present with nonspecific abdominal pain due to infarction, an enlarging abdominal mass with associated infection, intestinal obstruction due to adhesive bands of implants, gastrointestinal hemorrhage or hydronephrosis (3). Management of splenosis depends on the patient's symptoms. In general, it is accepted that asymptomatic implants should not be removed because splenic tissue may be immunologically functional and thus useful for the patient. Since this benign condition may mimic metastases, it should be kept in mind in managing cancer patients with a history of post-traumatic splenectomy, in order to avoid unnecessary surgery or chemotherapy (4).

We report a case presenting with a pelvic mass, which was preoperatively mistaken for metastasis of breast carcinoma.

\section{Case Report}

A 38-year-old woman presented at the gynecology clinic for routine gynecological examination during breast cancer treatment. She had a locally advanced breast cancer (T4bN2M0). She had no family history of breast carcinoma. She had been treated with preoperative chemotherapy, (consisting of 5 -fluorouracil $600 \mathrm{mg} / \mathrm{m}^{2}$, doxorubicin $60 \mathrm{mg} / \mathrm{m}^{2}$, and cyclophosphamide $600 \mathrm{mg} / \mathrm{m}^{2}$ for four cycles with 21-day interval) and modified radical mastectomy. There was no evidence of residual tumor in the breast, but 14 of the resected 25 lymph nodes were metastatic. Histopathological examination had revealed a histological grade 3 invasive ductal carcinoma of the left breast. Estrogen receptor (ER) of the tumor was 
positive but progesterone receptor (PgR) was negative by immunohistochemistry. Negative c-erbB-2 overexpression by immunohistochemical staining was also observed in this tumor. She had a history of splenectomy due to traumatic rupture after a motor vehicle accident at the age of 13 years. On pelvic examination, the uterus was found of normal size. The left ovary was enlarged to $5 \mathrm{~cm}$. Transvaginal ultrasound (TVUSG) scanning showed a $60 \times 30 \mathrm{~mm}$ hyperechoic, hypervascular solid tumor which seemed to be of left ovarian origin. Carbohydrate antigen-125 (Ca-125) value was within normal limits. Magnetic resonance imaging (MRI) showed a 39x56×40 mm diameter mass hypointense on T1-weighted and hyperintense on T2-weighted image on the left adnexal side. Further exploration of the pelvic mass was required, because exact diagnosis and final treatment could not be determined. Before the operation, the patient was advised about the various surgical options and it was agreed that if the diagnosis was not definitive during surgery or if there was the slightest doubt, then total abdominal hysterectomy and bilateral salpingo-ooperectomy would be performed. On laparotomy, a normal sized uterus with a bluish-red mass of $4 \times 6 \mathrm{~cm}$ in diameter with a soft consistency was observed on its posterior left side. Bilateral ovaries, and peritoneal surfaces were viewed to be normal. There were no pelvic adhesions. Since the exact nature of the macroscopic lesion could not be determined, as previosly agreed with the patient, total abdominal hysterectomy and bilateral salpingooophorectomy was performed. Microscopy of the left ovary showed focal microscopic metastases (Figure 1) of breast carcinoma. The bluish-red mass of $6 \times 3.5 \times 2.5 \mathrm{~cm}$ in diameter with soft consistency which was observed on the posterior left side of uterus had a white pulp composed of lymphoid aggregates. It was embedded in a highly vascular red pulp composed of broad anastomosing venous sinuses (Figure 2).

\section{Discussion}

Splenosis is the autotransplantation of splenic tissue that usually follows traumatic rupture of the spleen. Buchbinder and Lipkoff first reported splenosis in 1939 (5). Since then, fewer than 100 cases have been reported in the literature. Gynaecological cases $(4,6,7)$ are only a minority of these because splenic tissue is capable of implanting on peritoneal surfaces, abdominal wall and omentum. Based on the location of splenic nodules, differential diagnoses to be considered may be endometriosis in the presence of pelvic implants (7), peritoneal mesothelioma in the case of peritoneal seeding (8), renal cancer (9) in the case of renal implants, abdominal lymphomas in the case of retroperitoneal locations mimicking lymph nodes (10), hepatic adenomas in the case of intra-hepatic implants (11) and peritoneal metastases. Ectopic splenic tissue most frequently occurs in the abdominal cavity, especially on the serosal surfaces of the small and large bowel, in the parietal peritoneum, the mesentery, and the diaphragm. Uncommon locations of splenosis have been reported on the female genital organs (7), the thoracic cavity (2), or as in our case, as an adnexial mass.

Muller followed patients who underwent posttraumatic splenectomy with ultrasonography and reported that presumed splenosis occurred in one third of the patients, but this was

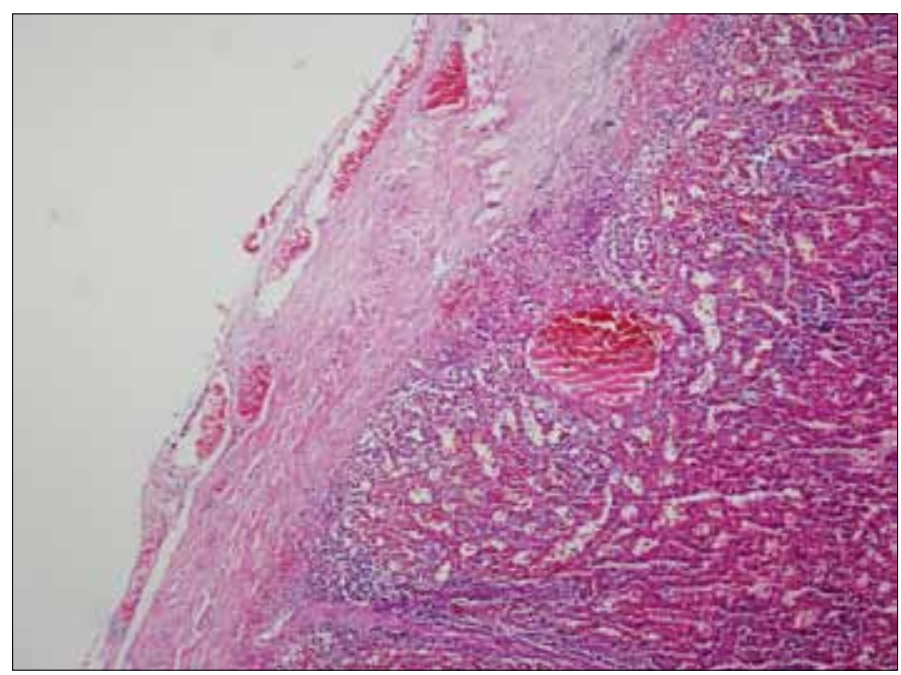

Figure 1. Ovarian metastases were pathologically consistent with primary invasive ductal carcinoma (Hematoxylin\&Eosin x200)

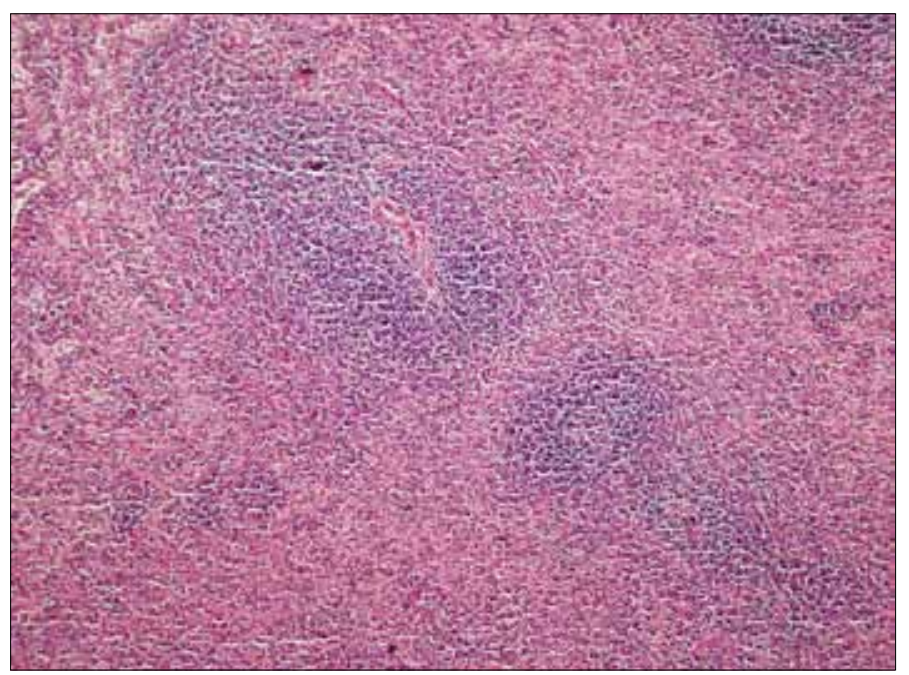

Figure 2. Bluish-red mass of $6 \times 3.5 \times 2.5 \mathrm{~cm}$ in diameter on the posterior serosal side of uterus had white and red pulp of splenic tissue (Hematoxylin\&Eosin x100)

not histologically confirmed (12). The incidence of splenosis is unknown since it is usually an incidental finding at surgery or autopsy (6).

Splenectomy for non-traumatic reasons may also lead to splenosis if splenic tissue is spilled onto the peritoneal surface at the time of surgery or if morcellation extraction of the spleen was used. Investigation in mice showed that growth of ectopic splenic tissue can be affected if splenectomy is incomplete and the circulating mediators released by the residual spleen are active (6). The pathogenesis of splenosis commences at the time of splenic rupture or splenectomy, when the splenic pulp disperses into the peritoneal cavity $(9,11)$. It is supposed that the number of nodules of ectopic splenic tissue that develop in the peritoneal cavity correlates with the severity of splenic injury. Another mechanism of splenic tissue transplantation is splenic vein emboli or hematogenous spread of splenic pulp, which is suggested by cases of intrahepatic and intracranial 
splenosis $(13,14)$. One theory suggests that splenic erythrocytic progenitor cells enter the liver via the portal vein, and then grow in response to tissue hypoxia (15).

Splenosis is usually asymptomatic. It is rarely of clinical significance. Occasionally, patients present with nonspecific abdominal pain due to infarction, an enlarging abdominal mass with associated infection, intestinal obstruction due to adhesive bands of implants, gastrointestinal hemorrhage or hydronephrosis. Pleurisy and hemoptysis may be the symptoms when thoracic splenosis occurs (16). Recurrence of Felty's syndrome also has been reported as a complication of splenosis, because splenic implants resume splenic function in 1-3 months (17).

The average reported interval between the spleen trauma and the diagnosis of splenosis is 19 years. Our patient had a 25 year interval between splenectomy and final diagnosis. The presumed diagnosis of splenosis can be made by the absence of Howell-Jolly bodies, siderocytes and other postcellular abnormalities on a peripheral blood smear.

Because most patients with splenosis are asymptomatic, ectopic splenic tissue is found incidentally during US, Computed Tomography (CT), or MRI examinations. MRI may be considered as an alternative modality for the identification of splenosis, in case of uncertainty of diagnosis with other examinations. Splenic implants have been described as hypointense on T1-weighted images and hyperintense on T2-weighted images, therefore similar to normal splenic tissue (18). In our case, magnetic resonance imaging showed a 56x40 mm diameter mass hypointense on T1-weighted and hyperintense on T2-weighted image.

The development of high frequency transvaginal scanning has facilitated the diagnosis of relatively small pelvic masses, and the advancement of laparoscopic surgical techniques may increase the frequency of diagnosis splenosis. Although the usual imaging modalities (US, CT, MRI) are helpful to localize and determine the size, structure and relations with adjacent organs, they are not specific. More specific and diagnostic studies using agents that are sequestered by reticulendothelial tissue, like 99m technetium sulphur colloid, 99m technetium labelled heat-denatured autologous red blood cells or 111 In-labelled platelet scans $(19,20)$ and recently ferumoxideenhaced MRI (21) have been used. Another specific method for the diagnosis of splenosis is MRI examination with intravenous administration of superparamagnetic iron oxide (SPIO), which is used for delineation of hepatic and splenic disease. Ectopic splenic tissue demonstrates the same decrease in signal intensity as the normal spleen after administration of SPIO particles (22). Management of splenosis depends on the patient's symptoms. In general, it is accepted that asymptomatic implants should not be removed because splenic tissue may be immunologically functional and thus useful for the patient. Furthermore, unnecessary excisions of the implants may lead to serious bleeding and damage to the surrounding organs. Since this benign condition may mimic metastases, it should be kept in mind in managing cancer patients with a history of post-traumatic splenectomy, in order to avoid unnecessary surgery or chemotherapy. In conclusion, splenosis must be considered in the differential diagnosis of previosly splenectomized patients who present with unexplained masses.

\section{Conflict of interest}

No conflict of interest was declared by the authors.

\section{References}

1. Ludtke FE, Mack SC, Schuff-Werner P, Voth E. Splenic function after splenectomy for trauma. Role of autotransplantation and splenosis. Acta Chir Scand 1989; 155: 533-9.

2. Madjar S, Weissberg D. Thoracic splenosis(review). Thorax 1994; 49: 1020-2. [CrossRef]

3. Neri A, Ovadia J, Braslavsky D. Abdominal splenosis mimicking abdominal carcinomatosis. Eur J Obstet Gynecol Reprod Biol 1986; 21: 177-9. [CrossRef]

4. Celiloğlu M, Doğan E, Kocoğlu S, Sanhan E. Splenosis presenting with adnexal mass: a case report. Arch Gynecol Obstet 2004; 270: 129-30.

5. Buchbinder JH, Lipkoff CJ. Splenosis: multiple peritoneal splenic implants following abdominal injury. Surgery 1939; 6: 927-30.

6. Stovall TG, Ling FW. Splenosis:report of case and review of literature. Obstet Gynecol Surv 1988; 43: 69-72. [CrossRef]

7. Zitzer P, Pansky M, Maymon R, Langer R, Bukovsky I, Golan A. Pelvic splenosis mimicking endometriosis, causing low abdominal mass and pain. Hum Reprod 1998; 13: 1683-5. [CrossRef]

8. Imbriaco M, Camera L, Manciuria A, Salvatore M. A case of multiple intra-abdominal splenosis with computed tomography and magnetic resonance imaging correlative findings. World $\mathrm{J}$ Gastroenterol 2008; 14: 1453-5.

9. Kiser JW, Fagien M, Clore FF. Splenosis mimicking a left renal mass. AJR 1996; 167: 1508-9.

10. Schenkein DP, Ahmed E. Case repords of the Massachusetts General Hospital. Weekly clinic-pathological exercises: Case disease and a pelvic mass. N Eng J Med 1995; 333: 784-91.

11. Gruen DR, Gollub MJ. Intrahepatic splenosis mimicking hepatic adenoma. AJR Am J Roentgenol 1997; 168: 725-6.

12. Muller U, Ruthlin M. Splenic neoformation following traumainduced splenectomy diagnosis and function. Swiss Surg 1995; 5: 230-5.

13. Rickert $\mathrm{CH}$, Maasjosthusmann U, Probst-Cousin S, August C, Gullotta F. A unique case of cerebral spleen. Am J Surg Pathol 1998; 22: 894-6. [CrossRef]

14. Grande M, Lapecorella m, Ianora AA, Longo S, Rubini G. Intrahepatic and widely distributed intraabdominal splenosis: multidetector CT, US, and scintigraphic findings. Intern Emerg Med 2008; 3: 265-7. [CrossRef]

15. Kwok CM, Chen YT, Lin HT, Su CH, Liu YS, Chiu YC. Portal vein entrance of splenic erythrocytic progenitor cells and local hypoxia of liver, two events cause intrahepatic splenosis. Med Hypothesis 2006; 67: 1330-2. [CrossRef]

16. Basile RM, Morales JM, Zupanec R. Splenosis. A cause of massive gastrointestinal hemorrhage Arch Surg 1983; 124: 1087-9.

17. Fleming CR, Dickson ER, Harrison EG, Jr. Splenosis: autotransplantation of splenic tissue. Am J Med 1976; 61: 414-9. [CrossRef]

18. Izzo L, Caputo M, Galati G. Intrahepatic accessory spleen: imaging features. Liver Int 2004; 216-7. [CrossRef]

19. Pumberger W, Wiesbauer P, Leitha T. Splenosis mimicking tumor recurrence in renal cell carcinoma: detection on selective spleen scintigraphy. J Pediatr Surg 2001; 36: 1089-91. [CrossRef]

20. Khosravi MR, Margulies DR, Alsabeh R, Nissen N, Phillips EH, Morgenstern L. Consider the diagnosis of splenosis for soft tissue masses long after any splenic injury. Am J Surg 2004; 70: 967-70.

21. Berman AJ, Zahalsky MP, Okon SA, Wagner JR. Distinguishing splenosis from renal masses using ferumoxide-enhanced magnetic resonance imaging. Urology 2003; 62: 748. [CrossRef]

22. Storm BL, Abbitt PL, Allen DA, Ross PR. Splenosis: superparamagnetic iron oxide-enhanced MR imaging. AJR Am J Roentgenol 1992; 159: 333-5. 